\title{
Productivity of industrial hemp and its utilisation for anaerobic digestion
}

\author{
A. Adamovičs, V. Dubrovskis \& R. Platače \\ Latvia University of Agriculture, Latvia
}

\begin{abstract}
Due to the growing shortage of fossil fuels, the use of alternative energy sources has become increasingly more popular; therefore it is necessary to study the suitability of various biomasses for energy production. In Latvia, maize is the dominating crop used for biogas production; thus it is desirable to cultivate a higher variety of crops having good economical characteristics and low environmental impact. Within the research, biometric parameters of ten industrial hemp cultivars were investigated. The characteristic indicators studied covered yield of hemp (Cannabis sativa L.) dry matter, digestion process for biogas production, average methane yield per unit of dry organic matter, average methane content, etc. Moreover, the suitability of two industrial hemp varieties, 'Futura75' and 'Uso31', for biogas production was tested. Research results conclude that under agro-ecological conditions of Latvia, all investigated plants may be successfully cultivated for energy production; moreover hemp leaves are the most suitable for biogas production. The aim of this study was the evaluation of possibilities to produce biogas from hemp.

Keywords: hemp (Cannabis sativa L.), productivity, anaerobic digestion, biogas, methane, energy crops.
\end{abstract}

\section{Introduction}

Industrial hemp (Cannabis sativa $\mathrm{L}$.) is one of the oldest home-grown and most versatile plants, and it has been cultivated over a long time period. In $19^{\text {th }}$ century, cultivation thereof in Europe declined, while recently this field has attracted interest again [1]. Nowadays industrial hemp has become important as a crop used for biomass production. Environmental concern and recent shortage of 
wood fibre have renewed utilisation of hemp for wide range of industrial products, including textiles, paper, and composite wood products [2].

Analyses of the latest trends in hemp cultivation and use as well as experimental results allow concluding that hemp cultivation and processing in Latvia are very perspective, since this plant is fast-growing and suitable for Latvia's agro-climatic conditions.

Sown areas of hemp in Latvia are registered only in 2008 and 2009, when hemp was grown on 250 ha. Recently in Latvia number of industrial hemp growers and area of cultivated land both have increased, and, in line with the data provided by Association of Industrial Hemp of Latvia, hemp plantations in 2012 occupied approximately 600 ha, showing growing interest in this agricultural sphere.

EU Directive stipulates that in $202020 \%$ of energy should be produced from alternative sources (in Latvia 40\%). Most part of it is taken by forest product biomass; however it should be noted that 1ha of agricultural land annually produces more energy than 1 ha of forest.

One of the most perspective energy sources is biogas that may be produced from energy plants within anaerobic fermentation. Currently in Latvia there are 53 biogas production plants (operating or being built), and energy plant used by them the most commonly is maize. 1ha yields high amount of biomass, and silage produced from it allows producing high biogas volume. Industrial hemp is one more similar energy plant. Suitability thereof may be assessed by finding out its energetic value, greenhouse gas emissions and environmental impact factors.

The amount of biogas obtained from various raw materials differs [3, 4]. Several researchers, when studying similar raw materials, have came to different conclusions and results depend upon substrate, conditions under which anaerobe process takes place, microorganisms (MO) content and other factors [5, 6]. One of the key factors influencing production of biogas is content of the organic matter OM, especially content of the three main OM groups: carbohydrates, proteins and lipids $[7,8]$.

Biogas may be produced from various waste, e.g., pig manure (yielding 0.34 $0.68 \mathrm{~m}^{3} / \mathrm{kg}$ DOM), cattle manure $\left(0.2-0.4 \mathrm{~m}^{3} / \mathrm{kg}\right.$ DOM $)$, poultry manure $(0.37-$ $0.64 \mathrm{~m}^{3} / \mathrm{kg}$ DOM), dairy produce waste $\left(0.62 \mathrm{~m}^{3} / \mathrm{kg}\right.$ DOM $)$, and sewage sludge $\left(0.2-0.6 \mathrm{~m}^{3} / \mathrm{kg} \mathrm{DOM}\right)$.

Various straws also may be one of the raw materials used to produce biogas. Usually they are used as bedding in livestock and poultry housings, and together with manure it is cheap material.

Also freshly mown grass may be used for biogas production. Grasses vary and biogas yielded from and biogas yielded from them will differ as well. Theoretically legumes should produce more biogas, as compared to grasses. Moreover, soil in which and climatic conditions under which grass has grown are of a great significance. Average content of grass dry matter comprises $12-25 \%$, content of DOM - 85-93\%, C:N ratio - 10-28.

Literature sources unfortunately only sometimes indicate the particular grass used, and thus data taken mainly from German researches in Latvia conditions not always are suitable for use. In Latvia, the potential of biogas production from 
various grasses has been studied only in few researches, and biogas yield from hemp has been investigated only once. Moreover, information acquired in foreign researches is very poor [9-14]. Currently Lund University in Sweden is conducting a hemp research; within the framework of it, rather good results were acquired, and it was concluded that industrial hemp grown under climatic conditions of south Sweden (Skone) is one of the energy plants that is the most suitable for biogas production.

The paper aims at finding out the suitability of hemp for biogas production.

\section{Materials and methods}

Field trials were carried out in 2011-2012, in Research and Study farm 'Pêterlauki' that is supervised by the Latvia University of Agriculture. 10 industrial hemp (Cannabis sativa L.) cultivars - 'Bialobrzeskie', 'Futura 75', 'Fedora 17', 'Santhica 27', 'Beniko', 'Ferimon', 'Epsilon 68', 'Tygra', 'Wojko' and 'Uso 31' were sown in the sod calcareous soil ( $\mathrm{pHKCl} \mathrm{6.7,} \mathrm{containing}$

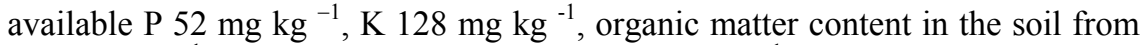
21 to $25 \mathrm{~g} \mathrm{~kg}^{-1}$ ). Total seeding rate comprised $50 \mathrm{~kg} \mathrm{ha}^{-1}$. The plots were fertilised as follows: N-120, P2O5- 90, K2O- $150 \mathrm{~kg} \mathrm{ha}^{-1}$. Hemp was sown by using Wintersteiger plot sowing machine in the middle of May, in $10 \mathrm{~m}^{2}$ plots, triplicate. Hemp was harvested by a small mower 'MF-70' when first matured seed appeared. Biometrical indices of the hemp seedlings, height and stem diameter in the middle thereof at harvesting time, amount of green and dry over ground mass, and fibre content were evaluated.

Biogas research was conducted with industrial hemp 'Futura 75 ' and 'USO 31'. The samples were tested with analyses necessary for successful anaerobic fermentation (AF) process - complete dry matter, ash and organic dry matter were measured. Basing on the results of analysis, the necessary quantity of hemp was calculated (100 g), and afterwards it was filled in bioreactors B2, B3 and B4 together with inoculum $(2000 \mathrm{~g})$ and water $(1500 \mathrm{~g})$. Remaining biogas potential of inoculum was verified by fermenting it in bioreactor B1. Substrate formation proportions were equal in all bioreactors: $2000 \mathrm{~g}$ of inoculum, $100 \mathrm{~g}$ of hemp to be fermented and $1500 \mathrm{~g}$ of warm water. Hemp was chopped - length of pieces in coarse chopping comprised 1-2 cm, while fine chopping was made with electric chopper that produced 1-5 mm pieces. Each substance was carefully weighted before filling it in bioreactors. Fermentation took place within single filling regime till biogas was not forming anymore. All parameters necessary to control the process - gas amount and content, $\mathrm{pH}$, pressure, temperature in room and bioreactors - were registered in a research journal every day. Also digestate was weighed and content thereof was analysed. Substrate in bioreactors was mixed with a specific device operated by mobile perforator. (Note: quantity of inoculum depended on the fact that it was possible to take such quantity out of continuously working bioreactor, thus ensuring equal conditions in all bioreactors. A fact that there was comparatively many inoculum, notably speeded up the start of stable AF process. 
The amount of biogas acquired was researched with laboratory device consisting of four 51 bioreactors. Each bioreactor is equipped with temperature maintenance and gas collection devices, as well as automatic registration apparatus; $\mathrm{pH}$ and pressure were controlled visually, afterwards registering parameters thereof in computer. Observations were made at $38 \pm 1{ }^{\circ} \mathrm{C}$ temperature under single filling regime. With an aim to speed up start of the process, inoculum for 51 bioreactors was taken from a working bioreactor. Microbiological inoculum was fermented with cattle manure that was added in each bioreactor ( $15 \%$ of total substrate). For substrate and dry matter of each substance, ash and organic dry matter were found out before filling them in bioreactors. Measurement precision comprised \pm 0.02 for $\mathrm{pH}, \pm 0.00251$ for gas and $\pm 0.1^{\circ} \mathrm{C}$ for temperature. Biogas content was measured periodically by finding out content of $\mathrm{CH}_{4}, \mathrm{CO}_{2}, \mathrm{O}_{2}$ and $\mathrm{H}_{2} \mathrm{~S}$.

Complete dry matter was measured with dry matter weights 'Shimazu' at temperature $120^{\circ} \mathrm{C}$, content of organic dry matter was found out with oven 'Nabertherm', drying samples under particular programme at $550^{\circ} \mathrm{C}$. Gas content was measured with gas analyser 'GA 2000', thus finding out content of methane, oxygen, carbon dioxide and hydrogen sulphide in biogas, as well as pressure and normal gas volume. Weighting was made with weights 'Kern FKB 16KO2', pH was measured with $\mathrm{pH}$ meter 'PP-50' with accessories (stationery).

Mean hemp sample was taken, and in biology laboratory of Latvia University of Agriculture content thereof was studied basing on standardised methodologies, in compliance with ISO 6496:1999. Mean sample and inoculum of each raw material group was investigated to find out full dry matter, organic dry matter and content of main elements; moreover each of the samples was weighted carefully as was the inoculum, afterwards mixing it with the rest of the mass. The same inoculum was used for all 4 samples - digestate from continuously working bioreactor. 0.71 bioreactors were filed with $20 \mathrm{~g}$ of hemp and 0.51 of inoculum (weight was registered with $0.2 \mathrm{~g}$ precision).

All bioreactors (altered standard containers) were connected with gas accumulation bags and taps, placed in oven under temperature $38 \pm 0.5^{\circ} \mathrm{C}$. Amount and content of gas produced was measured every day; bioreactors were shaken with the same frequency thus mixing substrate and reducing floating layer.

\section{Results and discussion}

Yield of hemp dry matter acquired within the field trials under agro-climatic conditions of Latvia on average comprised $17.78-18.41 \mathrm{tha}^{-1}$, depending on the variety. Cultivation year and selected variety notably affected hemp biomass yield (Table 1). In 2011, significantly higher yield of dry biomass (up to $20 \mathrm{t}$ $\mathrm{ha}^{-1}$ ) was obtained from cultivars 'Futura 75' (21.22 $\left.\mathrm{t} \mathrm{ha} \mathrm{ha}^{-1}\right)$, 'Beniko' (20.51 tha $\left.{ }^{-1}\right)$, 'Wojko' (20.33 $\left.\mathrm{t} \mathrm{ha}^{-1}\right)$ and 'Epsilon 68' $\left(20.26 \mathrm{t} \mathrm{ha}^{-1}\right)$, whereas the lowest - from cultivar 'Uso 31' (12.65 t ha' $\left.{ }^{-1}\right)$. In 2012, notably higher yield of dry biomass was produced by cultivars 'Futura 75 ' $\left(21.33 \mathrm{t} \mathrm{ha}^{-1}\right)$ and 'Tygra' $\left(20.87 \mathrm{t} \mathrm{ha}^{-1}\right)$, while the lowest - by cultivar 'Bialobrzeskie' (11.95 $\left.\mathrm{t} \mathrm{ha}^{-1}\right)$. 
Statistical assessment showed that meteorological conditions present during growing season influence total volume of the dry biomass yielded.

Table 1: $\quad$ Stem length of and biomass yielded from different industrial hemp varieties, 2011-2012.

\begin{tabular}{lcccccc}
\hline \multirow{2}{*}{ Variety } & \multicolumn{3}{c}{ Plant stem length, $\mathrm{m}$} & \multicolumn{3}{c}{ Dry biomass, $\mathrm{t} \mathrm{ha}^{-1}$} \\
\cline { 2 - 7 } & 2011 & 2012 & Average & 2011 & 2012 & Average \\
\hline Bialobrzeskie & 2.63 & 2.26 & 2.63 & 17.15 & 11.95 & 14.55 \\
\hline Futura 75 & 2.54 & 2.48 & 2.54 & 21.22 & 21.33 & 21.27 \\
\hline Fedora 17 & 2.47 & 2.59 & 2.47 & 16.60 & 18.23 & 17.42 \\
\hline Santhica 27 & 2.52 & 2.66 & 2.52 & 19.84 & 17.39 & 18.61 \\
\hline Beniko & 2.52 & 2.84 & 2.52 & 20.51 & 19.27 & 19.89 \\
\hline Ferimon & 2.41 & 2.84 & 2.41 & 16.90 & 18.59 & 17.75 \\
\hline Epsilon 68 & 2.50 & 2.88 & 2.50 & 20.26 & 12.89 & 16.57 \\
\hline Tygra & 2.49 & 3.06 & 2.49 & 18.61 & 20.87 & 19.74 \\
\hline Wojko & 1.95 & 2.83 & 1.95 & 20.33 & 19.91 & 20.12 \\
\hline Uso 31 & 2.32 & 2.58 & 2.32 & 12.65 & 17.38 & 15.01 \\
\hline Average & 2.44 & 2.70 & 2.44 & 18.41 & 17.78 & 18.09 \\
\hline LDS0.05 variety & 0.21 & & & 3.45 & \\
\hline LDS0.05 year & 0.09 & & & & \\
\hline $\begin{array}{l}\text { LDS0.05 } \\
\text { interaction } \\
\text { between variety } \\
\text { and year }\end{array}$ & 0.54 & & \\
\hline
\end{tabular}

The measurements obtained were summarised in tables and served as a base to calculate potential for producing biogas and methane in each bioreactor. Calculations were made bearing in mind also volume of gas produced in control bioreactor (the one from which inoculum was taken) (Table 2).

Table 2: $\quad$ Analysis of raw material.

\begin{tabular}{|l|c|c|c|c|c|c|c|c|}
\hline Raw/digester & $\mathrm{pH}$ & $\begin{array}{c}\text { TS } \\
(\%)\end{array}$ & TS (g) & $\begin{array}{c}\text { Ash, } \\
(\%)\end{array}$ & $\begin{array}{c}\text { DOM } \\
(\%)\end{array}$ & $\begin{array}{c}\text { DOM } \\
(\mathrm{g})\end{array}$ & $\begin{array}{c}\text { Weight } \\
(\mathrm{g})\end{array}$ & $\begin{array}{c}\text { Total } \\
\text { weight, } \\
(\mathrm{g})\end{array}$ \\
\hline $\begin{array}{l}\text { Inoculum } \\
\text { B 1-1 }\end{array}$ & 7.29 & 3.40 & 68.0 & 23.1 & 76.89 & 52.3 & 3500 & 52.29 \\
\hline $\begin{array}{l}\text { Coarse USO } \\
\text { 31 B1-2 }\end{array}$ & 7.19 & 63.97 & 64.0 & 7.2 & 92.85 & 59.4 & 3600 & 111.69 \\
\hline $\begin{array}{l}\text { Fine USO 31 } \\
\text { B1-3 }\end{array}$ & 7.22 & 55.13 & 55.1 & 7.5 & 92.49 & 51.0 & 3600 & 103.28 \\
\hline $\begin{array}{l}\text { USO 31 } \\
\text { leaves B1-4 }\end{array}$ & 7.25 & 62.96 & 62.9 & 16.1 & 83.84 & 52.8 & 3600 & 105.08 \\
\hline
\end{tabular}

Abbreviations: TS-total solids; DOM- dry organic matter. 
Hemp 'USO 31' with N150 from the trial field in Vircava was taken on 24 August 2013, in very dry and sunny day, and on 4 September 2013 they were filled in bioreactor. This fact and also fact that this hemp was not stored in suitable premises may explain comparatively high content of dry matter and organic dry matter. Anaerobe fermentation lasted for 53 days. Results of digestate analyses are shown in Table 3.

Table 3: $\quad$ Results of digestate analyses.

\begin{tabular}{|l|l|l|l|l|l|l|c|}
\hline Raw/digester & $\mathrm{pH}$ & $\begin{array}{c}\mathrm{TS}, \\
(\%)\end{array}$ & $\begin{array}{l}\mathrm{TS} \\
(\mathrm{g})\end{array}$ & $\begin{array}{l}\text { Ash, } \\
(\%)\end{array}$ & $\begin{array}{l}\text { DOM., } \\
(\%)\end{array}$ & $\begin{array}{c}\text { DOM, } \\
(\mathrm{g})\end{array}$ & $\begin{array}{c}\text { Weight, } \\
(\mathrm{g})\end{array}$ \\
\hline $\begin{array}{l}\text { Inoculum B } \\
1-1\end{array}$ & 7.32 & 2.18 & 66.2 & 25.62 & 74.38 & 49.2 & 3028 \\
\hline $\begin{array}{l}\text { Coarse USO } \\
\text { 31 B1-2 }\end{array}$ & 7.41 & 2.62 & 79.4 & 23.01 & 76.99 & 61.1 & 3030 \\
\hline $\begin{array}{l}\text { Fine USO 31 } \\
\text { B1-3 }\end{array}$ & 7.36 & 2.41 & 75,2 & 21.58 & 78.42 & 59.0 & 3120 \\
\hline $\begin{array}{l}\text { USO 31 } \\
\text { leaves B1-4 }\end{array}$ & 7.48 & 2.56 & 81.1 & 28.14 & 71.86 & 58.3 & 3168 \\
\hline
\end{tabular}

In all bioreactors gas was appearing evenly, and it happened already within the first days, except of control bioreactor, which contained only inoculum and water. In this reactor only small amount of gas was produced, and it means that inoculum contained very small quantity of not decomposed organic matter that is consumed by bacteria. Biogas and methane yields produced in all bioreactors are shown in Table 4.

Table 4: $\quad$ Biogas and methane produced from 'USO 31'.

\begin{tabular}{|c|c|c|c|}
\hline Raw/digester & $\begin{array}{c}\text { Biogas } \\
(1)\end{array}$ & $\begin{array}{c}\text { Biogas } \\
(1 / \mathrm{g} \mathrm{DOM})\end{array}$ & $\begin{array}{c}\text { Methane } \\
(\mathrm{l} / \mathrm{g} \text { DOM })\end{array}$ \\
\hline Inoculum B 1-1 & 0.6 & 0.011 & 0.003 \\
\hline Coarse USO 31 B1-2 & 22.93 & 0.376 & 0.195 \\
\hline Fine USO 31 B1-3 & 22.58 & 0.431 & 0.230 \\
\hline USO 31 leaves B1-4 & 30.32 & 0.563 & 0.334 \\
\hline
\end{tabular}

The highest amount of biogas and methane was produced in bioreactor B1-4 that was fermenting chopped leaves. It may be explained by the fact that hemp stems contain comparatively more cellulose and lignin that are more difficulty degradable by bacteria.

When calculating volumes of biogas and methane obtained, also biogas and methane produced from control inoculum was taken into account (it was subtracted from the total volume acquired in each bioreactor). Average indicators of each group were calculated as well. Results of raw material analyses are summarised in Table 5. 
Table 5: $\quad$ Results of raw material analyses.

\begin{tabular}{|l|c|c|c|c|c|c|c|c|}
\hline Raw/digester & $\begin{array}{c}\mathrm{pH} \\
\text { substrate }\end{array}$ & TS (\%) & TS (g) & $\begin{array}{c}\text { Ash } \\
(\%)\end{array}$ & $\begin{array}{c}\text { DOM } \\
(\%)\end{array}$ & $\begin{array}{c}\text { DOM } \\
(\mathrm{g})\end{array}$ & $\begin{array}{c}\text { Weight } \\
(\mathrm{g})\end{array}$ & $\begin{array}{c}\text { Total } \\
\text { DOM(g) }\end{array}$ \\
\hline $\begin{array}{l}\text { Coarse Futura } \\
75 \text { R2-4 }\end{array}$ & 7.31 & 41.62 & 8.3 & 9.1 & 90.9 & 7.6 & 520 & 16.33 \\
\hline $\begin{array}{l}\text { Inoculum } \\
\text { R1,R16 }\end{array}$ & 7.29 & 2.35 & 11.8 & 25.4 & 74.6 & 8.8 & 500 & 8.76 \\
\hline $\begin{array}{l}\text { Fine Futura } \\
75 \\
\text { R5-8 }\end{array}$ & 7.32 & 43.39 & 8.7 & 4.5 & 95.5 & 8.3 & 520 & 17.05 \\
\hline $\begin{array}{l}\text { Fine USO 31 } \\
\text { R9-12 }\end{array}$ & 7.28 & 55.13 & 11.0 & 7.5 & 92.5 & 10.2 & 520 & 18.96 \\
\hline $\begin{array}{l}\text { USO 31 } \\
\text { leaves R13- } \\
15\end{array}$ & 7.25 & 62.96 & 12.6 & 16.2 & 83.8 & 10.6 & 520 & 19.32 \\
\hline
\end{tabular}

As it can be seen in Table 5, hemp has high content of dry matter (41.62$62.96 \%$ ) and organic dry matter. It may be explained by the fact that hemp was harvested in dry weather and before chopping kept in dry premises. Results of the digestate analyses are compiled in Table 6.

Table 6: $\quad$ Average results of digestate analyses.

\begin{tabular}{|c|c|c|c|c|c|c|c|}
\hline Raw/digester & $\begin{array}{c}\mathrm{pH} \\
\text { substrate }\end{array}$ & $\begin{array}{c}\mathrm{TS} \\
(\%)\end{array}$ & $\begin{array}{c}\mathrm{TS} \\
(\mathrm{g})\end{array}$ & $\begin{array}{c}\text { Ash } \\
(\%)\end{array}$ & $\begin{array}{c}\text { DOM } \\
(\%)\end{array}$ & $\begin{array}{c}\mathrm{DO} \\
\mathrm{M}(\mathrm{g})\end{array}$ & $\begin{array}{c}\text { Weight } \\
(\mathrm{g})\end{array}$ \\
\hline $\begin{array}{c}\text { Coarse } \\
\text { Futura 75 } \\
\text { R2-4 }\end{array}$ & 7.17 & 3.58 & 18.2 & 23.8 & 76.2 & 139 & $\begin{array}{c}508.2 \\
\pm 3.1\end{array}$ \\
\hline $\begin{array}{c}\text { Inoculum } \\
\text { R1, R16 }\end{array}$ & 7.45 & 2.30 & 11.5 & 26.5 & 73.5 & 8.4 & 498.9 \\
\hline $\begin{array}{c}\text { Fine Futura } \\
75 \text { R5-8 }\end{array}$ & 7.08 & 3.24 & 16.6 & 22.0 & 78.0 & 12.9 & 511.1 \\
\hline $\begin{array}{c}\text { Fine USO 31 } \\
\text { R9-12 }\end{array}$ & 7.06 & 3.06 & 15.6 & 21.4 & 78.7 & 12.3 & 510.0 \\
\hline $\begin{array}{c}\text { USO 31 } \\
\text { leaves R13- } \\
15\end{array}$ & 7.29 & 3.39 & 17.3 & 29.3 & 70.7 & 12.2 & 510.2 \\
\hline
\end{tabular}

Biogas and methane volume yielded from coarse chopped 'Futura 75' are presented in Table 7.

Biogas and methane volume yielded from fine chopped 'Futura 75 ' is shown in Table 8.

Biogas and methane yield acquired from fine chopped 'USO 31' is summarised in Table 9. 
1052 Energy Production and Management in the 21st Century, Vol. 2

Table 7: $\quad$ Biogas and methane yield from coarse 'Futura 75'.

\begin{tabular}{|l|c|c|c|}
\hline \multicolumn{1}{|c|}{ Raw/digester } & $\begin{array}{c}\text { Biogas } \\
(1)\end{array}$ & $\begin{array}{c}\text { Biogas } \\
(1 / \mathrm{g} \text { DOM })\end{array}$ & $\begin{array}{c}\text { Methane } \\
(1 / \mathrm{g} \text { DOM })\end{array}$ \\
\hline $\begin{array}{l}\text { Coarse Futura 75 } \\
\text { R2 }\end{array}$ & 2.8 & 0.370 & 0.177 \\
\hline $\begin{array}{l}\text { Coarse Futura 75 } \\
\text { R3 }\end{array}$ & 2.7 & 0.357 & 0.172 \\
\hline $\begin{array}{l}\text { Coarse Futura 75 } \\
\text { R4 }\end{array}$ & 2.9 & 0.383 & 0.185 \\
\hline Inoculum R1 & 0.1 & 0.011 & 0.002 \\
\hline
\end{tabular}

Table 8: $\quad$ Biogas and methane yield from fine 'Futura 75'.

\begin{tabular}{|l|c|c|c|}
\hline \multicolumn{1}{|c|}{ Raw/ digester } & $\begin{array}{c}\text { Biogas } \\
(1)\end{array}$ & $\begin{array}{c}\text { Biogas } \\
(1 / \mathrm{g} \text { DOM })\end{array}$ & $\begin{array}{c}\text { Methane } \\
(1 / \mathrm{g} \text { DOM })\end{array}$ \\
\hline Fine Futura 75 R5 & 4.0 & 0.481 & 0.245 \\
\hline Fine Futura 75 R6 & 4.0 & 0.482 & 0.246 \\
\hline Fine Futura 75 R7 & 3.9 & 0.470 & 0.240 \\
\hline Fine Futura 75 R8 & 4.1 & 0.530 & 0.270 \\
\hline Inoculum R1 & 0.1 & 0.011 & 0.002 \\
\hline
\end{tabular}

Table 9: $\quad$ Biogas and methane yield from coarse 'USO 31'.

\begin{tabular}{|l|c|c|c|}
\hline \multicolumn{1}{|c|}{ Raw/digester } & $\begin{array}{c}\text { Biogas } \\
(\mathrm{l})\end{array}$ & $\begin{array}{c}\text { Biogas } \\
(\mathrm{l} / \mathrm{g} \text { DOM })\end{array}$ & $\begin{array}{c}\text { Methane } \\
(1 / \mathrm{g} \mathrm{DOM})\end{array}$ \\
\hline Fine USO 31 R9 & 4.5 & 0.441 & 0.226 \\
\hline Fine USO 31 R10 & 4.1 & 0.402 & 0.205 \\
\hline Fine USO 31 R11 & 4.3 & 0.422 & 0.216 \\
\hline Fine USO 31 R12 & 4.3 & 0.421 & 0.215 \\
\hline Inoculum R1 & 0.1 & 0.011 & 0.002 \\
\hline
\end{tabular}

Biogas and methane yield obtained from chopped 'USO 31' leaves is shown in Table 10.

Table 10: $\quad$ Biogas and methane yield from 'USO 31' leaves.

\begin{tabular}{|c|c|c|c|}
\hline Raw/digester & Biogas (1) & $\begin{array}{c}\text { Biogas } \\
(\mathrm{l} / \mathrm{g} \text { DOM })\end{array}$ & $\begin{array}{c}\text { Methane } \\
(1 / \mathrm{g} \text { DOM })\end{array}$ \\
\hline Leaves USO 31 R13 & 6.7 & 0.634 & 0.375 \\
\hline Leaves USO 31 R14 & 6.3 & 0.507 & 0.354 \\
\hline Leaves USO 31 R15 & 6.5 & 0.616 & 0.365 \\
\hline Inoculum R1 & 0.1 & 0.011 & 0.002 \\
\hline
\end{tabular}

Average biogas and methane volume yielded from various hemps is summarised in Table 11. The highest amount of methane was obtained from 
chopped 'USO 31' leaves. It may be explained by the fact that leaves contain less cellulose and lignin than stems and more juice. Comparison of same fineness 'Futura 75' and 'USO 31' shows that more methane was produced from 'Futura 75.

Table 11: Average biogas and methane volume yielded from hemp.

\begin{tabular}{|l|c|c|c|c|c|}
\hline Raw/digester & $\begin{array}{c}\text { Biogas } \\
(\mathrm{l})\end{array}$ & $\begin{array}{c}\text { Biogas } \\
(\mathrm{l} / \mathrm{g} \\
\mathrm{DOM})\end{array}$ & $\begin{array}{c}\text { Methane } \\
(\%)\end{array}$ & $\begin{array}{c}\text { Methane } \\
(\mathrm{l}, \text { without } \\
\text { inoculum })\end{array}$ & $\begin{array}{c}\text { Methane } \\
(\mathrm{l} / \mathrm{g} \text { DOM } \\
\text { added })\end{array}$ \\
\hline Inoculum & 0.1 & 0.011 & 20.3 & 0.02 & 0.002 \\
\hline $\begin{array}{l}\text { Coarse } \\
\text { Futura 75 } \\
\text { R2-4 }\end{array}$ & 2.8 & 0.370 & 48.21 & 1.33 & $0.177 \pm 0.007$ \\
\hline $\begin{array}{l}\text { Fine Futura } \\
75 \text { R5-8 }\end{array}$ & 4.0 & 0.482 & 51.03 & 2.036 & $0.246 \pm 0.023$ \\
\hline $\begin{array}{l}\text { Fine USO 31 } \\
\text { R9-12 }\end{array}$ & 4.3 & 0.422 & 51.18 & 2.206 & $0.216 \pm 0.011$ \\
\hline $\begin{array}{l}\text { USO 31 } \\
\text { leaves R13- } \\
15\end{array}$ & 6.5 & 0.616 & 59.25 & 3.852 & $0.365 \pm 0.01$ \\
\hline
\end{tabular}

Average methane yielded from 'USO 31' leaves $(0.365 \pm 0.011 / \mathrm{g}$ DOM) is very good result, as compared to other energy crops.

Studies on 'Futura 75 ' resulted in $234-290 \mathrm{~m}^{3} / \mathrm{t}$ DOM of methane. Researches on the influence of harvesting time on methane yield allowed concluding that influence is insignificant, as it is only slightly smaller than one acquired from hemp harvested in October [15]. More notable effect is left by pre-processing, and, if samples are chopped to $1-2 \mathrm{~mm}$ pieces, $290 \mathrm{~m}^{3} / \mathrm{t}$ of methane is acquired.

\section{Conclusions}

1. The industrial hemp cultivars 'Bialobrzeskie', 'Futura 75', 'Fedora 17', 'Santhica 27', 'Beniko', 'Ferimon', 'Epsilon 68', 'Tygra', 'Wojko' and 'Uso 31 ' could be successfully grown in Latvia for biomass and fiber production. The highest biomass yield, during both trial years, was obtained from cultivar 'Futura 75'. According to the data we can conclude that the growing season and the selected industrial hemp variety had a significant $(p<0.05)$ effect on hemp yield.

2. In Latvia, weather produced hemp is used in the production of biogas and provides high methane extraction.

3. Greater methane outcome provides finely chopped hemp stalks and leaves.

4. Common biogas extraction field unit is influenced by the variety of hemp productivity. 


\section{Acknowledgement}

The research was supported by the grant of the Ministry of Agriculture of the Republic of Latvia, Agreement No. 160413/S99.

\section{References}

[1] Kortekaas, S., Contribution of extractives to methanogenic toxicity of hemp black liquor. Journal of Fermentation and Bioengineering, 80(4), 383-388, 1995.

[2] Feasibility of Industrial Hemp Production in the United States Pacific Northwest. Oregon State University. Online. www.extension.oregon state.edu/catalog/html/sb/sb681/

[3] Baader, B., Done, E., Brenndorfer, M., Biogas Theory und Praxis, p. 148, 1982.

[4] Angelidaki, I., Alves, M., Bolzonella, D., Borzacconi, L., Campos, J. L., Guwy, A. J., Kalyuzhnyi, S., Jenicek, P., Lier, J. B., Def ning the biomethane potential (bmp) of solid organic wastes and energy crops: a proposed protocol for batch assays. Water Science \& Technology - WST, 59(5), pp. 927-934, 2009.

[5] Lin, J. G., Ma, Y. S., Chao, A. C., Huang, C. L., BMP test on chemically pretreated sludge. Bioresour. Technol. 68(2), pp. 187-192, 1999.

[6] Dubrovskis,V., Plūme, I., Kotel̦enecs, V., Zabarovskis E., Biogas production and biogas potential from agricultural biomass and organic residues in Latvia. Engineering for rural development, Jelgava, pp. 566571, 2011.

[7] Fernandez, B., Porrier, P. \& Chamy, R., Effect of inoculumsubstrate ratio on the start-up of solid waste anaerobic digesters. Water Sci. Technol. 44(4), pp. 103-108, 2001.

[8] Leitfaden Biogas. Von der Gewinnung zur Nutzung. Online. http://www.fnr-server.de/ftp/pdf/literatur/pdf_208-leitfaden_biogas_2010_ neu.pdf

[9] Adamovičs, A., Dubrovskis, V., Plūme, I., Jansons, Ā., Lazdiṇa, D., Lazdiňš, A., Biomasas izmantošanas ilgtspējības kritēriju pielietošana un pasākumu izstrāde (Criteria for biomass use sustainability and development of measures), Vides projekti, Rīga, pp. 125-159, 2009.

[10] Joy, J. E., Stanley J.,W atson, S. J., John A., Benson, J. R., Marijuana and Medicine: Assessing The Science Base. Washington D.C: National Academy of Sciences Press, p. 256, 1999.

[11] Kamat, J., Roy, D. N., Goel, K. Effect on harvesting age on the chemical properties of hemp plants. Journal of Wood Chemistry and Technology, 22(4), pp. 285-293, 2002.

[12] Struik, P. C., Amaducci, S., Bullard, M. J., Stutterheim, N. C., Venturi, G., Cromack, H. T. H., Agronomy of fibre hemp (Cannabis sativa L ). in Europe. An International Journal Industrial Crops and Products 11, pp. 107-118, 2000. 
[13] Projektes "Handreichung Biogasgewinnung und -nutzung", Leitfaden Biogas. Von der Gevinnung zur Nutzung., p. 267, 2010.

[14] Thomas, P. Svensson, S., Andersson, A., Mattsson, J. E., Energy balances for biogas and solid biofuel production from industrial hemp. Biomass and Bioenergy, 35(7), pp. 3040-3049, 2011.

[15] Pakarinen, A., Maijala, P., Stoddard, F., Santanen, A., Kymalainen, M., Viikari, L., Evaluation of annual bioenergy crops in the Boreal zone for biogas and ethanol production. Biomass Bioenergy 35, pp. 3071-3078, 2011. 